\title{
Sources Of Non-Performing Loans In Turkish Banking System
}

Gokhan Karabulut, (E-mail: gbulut@istanbul.edu.tr), Istanbul University, Istanbul, Turkey Mehmet Huseyin Bilgin, (E-mail: mhbilgin@khas.edu.tr), Kadir Has University, Istanbul, Turkey

\begin{abstract}
The purpose of this paper is to examine the impact of the unlimited deposit insurance on nonperforming loans and market discipline. Deposit insurance program play a crucial role in achieving financial stability. Governments in many advanced and developing economies established deposit insurance schemes for reducing the risk of systemic failure of banks. Deposit insurance has a beneficial effect of reducing the probability of a bank run. However deposit insurance systems have its own set of problems. Deposit insurance systems create moral hazard incentives that encourage banks to take excessive risk. Turkey established an explicit deposit insurance system in 1960. Until 1994, the coverage determined by a flat rate but in that date, Turkey experienced a major economic crisis. In April 1994, Turkish government started to apply an unlimited deposit insurance scheme to restore banking system stability. Unlimited deposit insurance caused a remarkable increase at non-performing loans. This paper empirically estimates the impact of unlimited deposit insurance system on non-performing bank loans (NPLs) and analyses the other potential sources of NPLs.
\end{abstract}

Keywords: Deposit Insurance, Non-Performing Loans, Credit Allocation, Turkish Banking System

\section{INTRODUCTION}

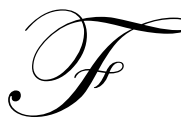

inancial crises became a serious threat for the world economy especially after the financial deregulation process of the 1980s. This process and increased competition affected banking system safety and soundness therefore banking system vulnerability increased during last decades. It is agreed that a stable macroeconomic environment is not sufficient for achieving high and sustained growth, macroeconomic stability needs to be complemented and strengthened by the development of a strong financial sector. The relationship between financial sector and real sector makes the intermediation efficiency, the indicator of capital accumulation and productive efficiency. Therefore the stability of financial system is very important to economic growth. After the banking deregulation process in 1980's, international over-borrowing syndrome became an important threat for the banking systems of developing countries. In this process, the banking sectors in developing countries faced with the default risk because of inefficient portfolios, specifically, in terms of international funds. Over-borrowing problem follows a cyclical pattern in the recovery phase of business cycle. Increased demand leads prices to rise and attracts new investment. In a feedback relationship the new investments stimulates income.

Minsky (1977) focused on over-investment and over-lending problems in order to explain financial crises and call this phenomenon "euphoria". Following Minsky (1977) and Kindleberger (1989), the over-borrowing problem was modelled by McKinnon and Phil (1996). Corsetti, Pesenti and Roubini (1998) emphasized the role of implicit and explicit bail out guarantees on moral hazard problem. Under these guarantees, banks take excessive risk. Over-lending problem occurs through insufficient monetary capacity, asymmetric information and deposit insurance scheme. Current studies conclude that over-borrowing and bailout guarantees can cause severe currency and banking crises (twin crises). These models are called third generation models in currency crisis literature. 
In emerging markets, open economy conditions may cause banks to become vulnerable to exchange rate fluctuations under international over-borrowing. But there are also some other risks, which are stimulated by this problem, such as interest rate and credit risks. If banks switch these international funds in order to finance budget deficits by holding government bonds in their portfolios, interest rate risk would increase. But if moral hazard leads banks to take unhedged foreign exchange position in order to fulfill the domestic over-borrowing demands by the upswing of the business cycle, this would increase credit risk. Deposit insurance also has played a crucial role in this process, because the banks may implicitly transfer most of the risk to the government through the deposit insurance scheme.

Banks are profit maximizing institutions but the risks that they face are quite different from non-financial institutions and subject to several kinds of specific risk such as liquidity, credit risk and interest rate risk. A failure of a bank changes the expectations of bank depositors and investors. A sudden change of the expectations in the same direction can lead systemic problems without government intervention. This process usually ends with a banking crisis. Central banks and supervisory authorities need to always be prepared to respond effectively to bank distress and failure, to minimize contagion risk and restore investor confidence in the financial system.

Deposit insurance is an effective way to prevent financial instability. A well constructed deposit insurance system is important for smooth functioning of the payments system and credit allocation mechanism. Deposit insurance systems protect the less sophisticated depositors and help to prevent bank runs. On the other hand, deposit insurance schemes are not costless. Deposit insurance not only increases stability of banking system by protecting depositors, but also stimulates the moral hazard problem of insured banks. Without depositors monitoring, deposits shift to unsound banks. The shift of funds into high risk projects can lead to less productive use of society's limited resources. Therefore, achieving financial stability has been expensive involving wealth transfer at spectacular dimension. The coverage of deposit insurance is also very important. Under an unlimited deposit insurance scheme these negative effects can be strong.

The paper is organized into four sections: Section 1 summarizes the history and the current situation of deposit insurance systems, section 2 discusses the Turkish deposit insurance scheme, section 3 empirically analyses the behavior and the sources non-performing loans and section 4 presents conclusions.

\section{DEPOSIT INSURANCE SYSTEMS AND MORAL HAZARD}

Every developed country has a deposit insurance system; but as Schuler (1989) mentions, in all except the United States, deposit insurance is a recent innovation dating from the 1960s and 1970s. New York State started to implement the first deposit insurance scheme in 1829. Six states before and eight states after the civil war had adapted deposit insurance. Until 1930s there was a very little support for nationwide deposit insurance system, but US suffered severe banking system problems especially between 1929 and 1933. Therefore, the United States pioneered modern-day deposit insurance systems. The national banking act of 1933 created the Federal Deposit Insurance Corporation (FDIC). The act also gave FDIC regularity and supervision functions. FDIC's deposit insurance coverage initially set as at $\$ 2500$ then rose in the same year to $\$ 5000$. Today FDIC provides explicit coverage up to $\$ 100000$ since 1980. FDIC charged a flat rate deposit insurance premiums until 1993 and in 1993 began to implicate a risk based premiums pricing.

After deposit insurance systems, financial distresses are no longer characterized by bank runs, but there is a trade off between preventing a crisis and creating moral hazard. With or without deposit insurance systems, bank owners and managers have incentives to take risks, but deposit insurance stimulates these risks because of the insufficient depositor monitoring. Insured depositors are indifferent the risks taken by their banks. These behaviors of depositors and bank owners weaken market discipline. Therefore, under deposit insurance systems regulators should fill this gap by effective regulation and supervision. Governments have to limit moral hazard without losing the benefits of deposit insurance. According to Lawrence, Goldberg and Harikumar (1991), perfect monitoring or risk based deposit premiums can eliminate moral hazard problem if information were symmetric between bank managers and the insurance company. Therefore, regulation plays a more important role under deposit insurance systems. 
Another important factor which affects the depositor's monitoring incentives is the coverage limit of deposit insurance system. A study group was created for working on deposit insurance systems at financial stability forum in November 1999 (G-7 finance ministers and Central Bank governors convened to promote international financial stability). According to group's report (Financial Stability Forum, 2001), a credible limited-coverage deposit insurance system should be established in order to achieve financial stability.

The objective of an effective deposit insurance scheme is to protect small depositors. There are only five countries which have unlimited deposit insurance systems in the world (Turkey, Mexico, Japan, South Korea and Ecuador).

\section{DEPOSIT INSURANCE SYSTEM IN TURKEY}

Recent years have witnessed a remarkable change in banking sector in Turkey. Currently, there are 47 banks registered in Turkey. In the beginning of 2000, there were 79 banks in the system. Therefore 32 banks became insolvent during the stabilization program which began in January 2000. Asset sizes of currently operating banks were shown in Table 1.

Table 1: Asset Sizes and Banks

\begin{tabular}{lcccccc}
\multicolumn{1}{c}{ Billion Dollar } & $\mathbf{0 - 1}$ & $\mathbf{1 - 2}$ & $\mathbf{2 - 5}$ & $\mathbf{5 - 1 0}$ & $\mathbf{1 0 - 2 0}$ & $\mathbf{2 0 +}$ \\
\hline Commercial Banks & 14 & 5 & & & & \\
State Owned Banks & 0 & 0 & 0 & 5 & 2 & 6 \\
Private Banks & 4 & 4 & 2 & 0 & 0 & 3 \\
Foreign Banks & 10 & 1 & 0 & 2 & 0 & 3 \\
Investment Banks & 10 & 0 & 3 & 0 & 0 & 0 \\
Sectors & 24 & 5 & 5 & 5 & 2 & 6 \\
\hline
\end{tabular}

Source: The Banks Association of Turkey, Banks in Turkey, 2005.

Table 2 shows the asset sizes and market shares of commercial banks and other financial institutions.

Table 2: Market Shares (\%)

\begin{tabular}{llllllllll} 
& \multicolumn{3}{c}{ Total Assets } & \multicolumn{3}{c}{ Total Deposits } & \multicolumn{3}{c}{ Total Credits } \\
& $\mathbf{9 0}$ & $\mathbf{9 9}$ & $\mathbf{0 6}$ & $\mathbf{9 0}$ & $\mathbf{9 9}$ & $\mathbf{0 6}$ & $\mathbf{9 0}$ & $\mathbf{9 9}$ & $\mathbf{0 6}$ \\
\hline & & & & & & & & & \\
Commercial Banks & 91 & 95 & 97 & 100 & 100 & 100 & 88 & 90 & 95 \\
State Owned Banks & 45 & 35 & 32 & 49 & 40 & 38 & 45 & 28 & 21 \\
Private Banks & 43 & 55 & 60 & 49 & 57 & 57 & 40 & 59 & 67 \\
Foreign Banks & 3 & 5 & 5 & 2 & 3 & 5 & 3 & 3 & 7 \\
Investment Banks & 9 & 5 & 3 & - & - & 0 & 12 & 10 & 5 \\
Sectors & 100 & 100 & 100 & 100 & 100 & 100 & 100 & 100 & 100 \\
\hline
\end{tabular}

Source: The Banks Association of Turkey, Banks in Turkey, 2005.

Turkish deposit insurance system was established in 1960. The insurance was unlimited at the beginning but coverage became limited in 1983 (TL 3 Million). This coverage is expanded to TL 65 Million in 1992. In 1980s, Turkish financial system had been liberalized, but this process was not accompanied by modernization of the supervision and regulatory framework. On the other hand, government tried to stimulate short term capital inflows and effective demand by suppressing the exchange rate between 1989 and 1994. This process caused a large trade deficit which was unsustainable. In the beginning of the 1994, after a speculative attack exchange rates were allowed to float freely. 
Banks were vulnerable to fluctuations in the exchange rates because of their huge short positions. Thus Turkey faced currency crisis and banking crisis at the same time. Three banks ${ }^{1}$ became insolvent. Total deposit share of these banks was 5.75 percent in 1994. During March, total deposits come down by 12 percent relative to the month before and in April 5, government announced a series of fiscal and financial measures, but the recovery of confidence only began when government announced that they started to implement a full coverage deposit insurance scheme. Former deposit insurance system wasn't abolished, only became unlimited.

This new legal framework of deposit insurance made it possible to decrease monitoring costs of banks, because moral hazard risk became less important for depositors since full coverage exists. Thus, new deposit scheme made matters worse and Turkish banking system suffered from serious problems with non-performing loans.

\section{EMPIRICAL ANALYSES}

Shiers' study (Shiers, 1994) is one of the few that attempts to look directly at the relationship between the level of deposit insurance coverage and bank risks. Defining bank risk as the coefficient of variation of return on assets and using a one equation OLS model, he found a positive and significant relationship (Karels, 1998), but in this study it has been used chow-test to analyze the impact of the deposit insurance coverage on non-performing loans.

After analyzing the existence of a structural breakpoint we will estimate the determinants of nonperforming loans for the period after breakpoint using OLS. The existence of a threshold in 1994 can be considered as an evidence of the relationship between the insurance coverage and moral hazard. To examine this relationship, monthly data for the period 1987:1 to 2002:1 are used. The monthly data were obtained consolidated balance sheet tables of Turkish Banking System which published by Turkish Republic Central Bank regularly.

The existence of a structural change was analyzed using the equations as follows:

$$
\begin{array}{ll}
\operatorname{Ln}\left(\mathrm{NPL}_{\mathrm{i}}\right)=\alpha_{0}+\alpha_{0} \mathrm{t}_{\mathrm{i}} & \mathrm{i}=1987: 1-1994: 3 \\
\operatorname{Ln}\left(\mathrm{NPL}_{\mathrm{i}}\right)=\beta_{0}+\beta_{0} \mathrm{t}_{\mathrm{i}} & \mathrm{i}=1994: 4-2002: 1
\end{array}
$$

NPL: Non-performing Loans

t: Time

The chow test is statistically significant (F-value:407,164 and p-value :0). These results show that there is a strong structural change in non-performing loans. Besides these results, Graph 1 can be considered as an evidence of structural change.

\section{Graph 1: Breakpoint in 1994}

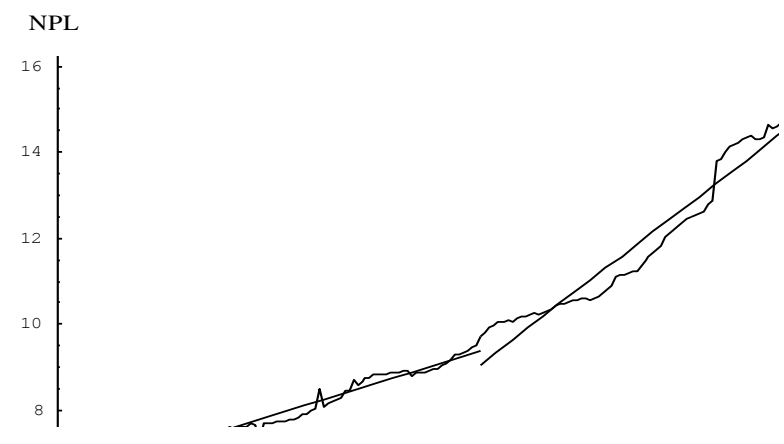

\footnotetext{
${ }^{1}$ Impexbank, TYT Bank and Marmara Bank.
} 
In order to understand which variable determine this accelerating pattern of NPLs through unlimited deposit insurance we will use OLS estimation method. To emphasize directly the impact of unlimited deposit insurance scheme the data for the period 1994:4 2006:10 are used.

Table 3: ADF Unit Root Test Statistics

\begin{tabular}{ccc} 
Variable & Level & Log Difference \\
\hline NPL & -1.73 & $-3.97^{* * * *}$ \\
DEP & $-4.13^{* * * *}$ & $-5.18^{* * * *}$ \\
CAP & $-2.58^{*}$ & $-4.51^{* * * *}$ \\
CBL & $-4.25^{* * *}$ & $-5.26^{* * *}$ \\
FB & $-3.16^{* *}$ & $-5.66^{* * *}$ \\
DB & -1.71 & $-5.29^{* * *}$ \\
\hline
\end{tabular}

Note: Superscripts $* * * . * * *$ denote statistical significance at $\% 10, \% 5$ and $\% 1$ levels respectively.

Analyzing Augmented Dickey-Fuller unit root test statistics indicate that (Table 3) model specification should be as in equation 3;

$$
\triangle L n N P L=\alpha_{0}+\alpha_{1} \Delta D E P+\alpha_{2} \Delta C A P+\alpha_{3} \Delta C B L+\alpha_{4} \Delta F B+\alpha_{5} \Delta D B+\varepsilon
$$

Where NPL is non-performing loans, DEP is deposits, CAP is share of capital in total assets, CBL is funds required from Turkish Republic Central Bank, FB is foreign borrowing, DB is domestic borrowing.

Table 4: Determinants of NPL: OLS Estimates. Standard Errors in Parenthesis

\begin{tabular}{cc} 
Explanatory Variables & NPL- Dependent Variable \\
\hline DEP & $1.61^{*}$ \\
& $(0.15)$ \\
CAP & 0.61 \\
& $(0.15)$ \\
CBL & 1.25 \\
& $(0.06)$ \\
FB & $-2.67^{* * *}$ \\
& $(0.06)$ \\
DB & -0.28 \\
& $(0.11)$ \\
Constant & -0.007 \\
R squared & $0.01)$ \\
Number of observations & 0.127 \\
\hline
\end{tabular}

Note: Significance at 10 percent and 1 percent level is indicated by *, *** respectively

OLS estimates indicate that unlimited deposit insurance system of Turkey triggered NPLs by damaging efficiency of allocation of deposits. With this new legal framework of deposit insurance, insolvency risk of a bank became less important for depositors since full coverage exists. Therefore, this process damaged also credit allocation mechanism and increased NPLs. As McKinnon and Phil (1996); Corsetti, Pesenti and Roubini (1998) emphasizes, the role of implicit and explicit bail out guarantees on moral hazard problem. Under these guarantees, banks take excessive risk. Over-lending problem occurs through insufficient monetary capacity, asymmetric information and deposit insurance scheme. These studies conclude that over-borrowing and bailout guarantees can cause severe currency and banking crises (twin crises). OLS results shows that, depositors decision are very important in this process and unlimited deposit insurance system affects these decision in a bad manner. It is a well 
known fact that foreign financial institutions monitoring and screening banks efficiently after lending them. According to OLS results, it can be concluded that, borrowing from foreign financial institutions decreases NPLs.

\section{CONCLUDING REMARKS}

This paper investigated the impact of unlimited deposit insurance on non-performing loans. Due to a financial crisis in 1994 government started to implement a full coverage deposit insurance scheme in Turkey. The new legal framework of deposit insurance made it possible to decrease monitoring costs of banks, because moral hazard risk became less important since full coverage exists. This situation caused a remarkable increase in nonperforming loans.

Chow test results indicate that there is a strong structural change in non-performing loans in 1994. OLS estimates indicate that unlimited deposit insurance system of Turkey triggered NPLs by damaging efficiency of allocation of deposits. With this new legal framework of deposit insurance, insolvency risk of a bank became less important for depositors since full coverage exists.

\section{REFERENCES}

1. $\quad$ Corsetti, G., P. Pesenti and N. Roubini. (1998). What Caused the Asian Currency and Financial Crisis: Part I, MIMEO, New York University.

2. Financial Stability Forum. (2001). International Guidance on Deposit Insurance a Consultative Process, Working Group Progress Report On Deposit Insurance.

3. Goldberg, G. and T. Harikumar. (1991). Risk-Taking Incentives of Banks and Risk-Adjusted Deposit Insurance, Journal of Financial Research, Vol. 14, No. 3, pp. 233-239.

4. Gorton, G. (1988). Banking Panics and Business Cycles, Oxford Economic Papers, Vol. 40, No. 4 (December), pp. 751-781.

5. Grossman, R. S. (1992). Deposit Insurance, Regulation and the Moral Hazard in the Thrift Industry: Evidence from the 1930s, American Economic Review, Vol. 82, No.4 (September), pp. 800-821.

6. Jacklin, C. J. and S. Bhattacharya. (1988). Distinguishing Panics and Information-based Bank Runs: Welfare and Policy Implications, Journal of Political Economy, Vol. 96, No. 3 (June), pp. 568-592.

7. Kane, E. J. (1986). Appearance and Reality in Deposit Insurance: The Case for Reform, Journal of Banking and Finance, No.10, pp.175-188.

8. Karels, G. V. (1998). The Relationship Between Bank Risk and Deposit Insurance Premiums, WDSI Conference.

9. Kindleberger, C. (1989). Manias, Panics and Crashes: A History of Financial Crises, Basic Books, New York.

10. McKinnon, R. I. and H. Phil. (1996). Credible Liberalizations and International Capital Flows: The Overborrowing Syndrome, in Takatoshi Ito and Anne O. Krueger (eds.), Financial Deregulation and Integration in East Asia, University of Chicago Press, NBER East Asia Seminar on Economics, Vol.5.

11. Minsky H. P. (1977). A Theory of Systemic Fragility, in E. Altman and A. Sametz (eds.), Financial Crises: Institutions and Markets in a Fragile Environment, John Wiley\&Suns, New York.

12. Park, S. and S. Peristiani. (1998). Market Discipline by Thrift Depositors, Journal of Money, Credit and Banking, Vol. 30, No. 3, Part 1 (August), pp. 347-364.

13. Schuler, K. (1989). Deposit Insurance Déja vu, The Freeman, Vol. 39, No.7 (July), pp. 265-269.

14. Shiers, A. F. (1994). Deposit Insurance and Banking System Risk: Some Empirical Evidence, The Quarterly Review of Economics and Finance, Vol. 34, No. 4, pp. 347-361.

15. The Banks Association of Turkey, Banks in Turkey, 2005.

16. Tulay, B., M. Alparslan and P. A. Erdonmez. (1999). Deposit Insurance System in Different Countries and Turkey, The Banks Association of Turkey Pub.

17. White, E. N. (1983). The Regulation and Reform of the American Banking System, 1900-1929, Princeton University Press, Princeton.

18. White, L. J. (1991). The S\&L Debacle: Public Policy Lessons for Bank and Thrift Regulation, Oxford University Press, New York. 